УДК 94 (477)

DOI 10.24919/2519-058x.4.111472

Катерина БУРЛАКА,

orcid.org/0000-0001-5135-1087

магістер-туризмознавець, факультет туризу та міжнародних комунікацій ДВНЗ «Ужсгородський національний університет» (Ужгород, Україна), katya.burlaka1@gmail.com

\title{
ПРОБЛЕМИ ТА ПЕРСПЕКТИВИ ОРГАНІЗАЦІЇ ІСТОРИЧНОГО ТУРИЗМУ НА ЗАКАРПАТТІ
}

У статті проаналізовано проблеми та перспективи розвитку історичного туризму у Закарпатській області. Авторка дійшла висновку, щуо різноманіттям історико-культурних пам'яток створюють необхідні передумовами для інтенсивного розвитку історичного і відповідно етнічного туризму у иььму регіоні.

Розкриття теми стало можливим завдяки використанню загальнонаукових методів пізнання: аналізу, синтезу, системності, узагальнення, конкретності, історизму та діалектичного. Використано також спеціально-наукові методи дослідження: історико-порівняльний, історико-синтетичний, історико-діахронний, емпіричного аналізу тощзо.

Ключові слова: історичний туризм, Закарпаття, історико-культурні пам'ятки, історичні ресурси, етнографічний туризм.

Лim. 13.

Kateryna BURLAKA,

Master of Tourism, Faculty of Tourism and International Communications State University Uzhgorod National University (Uzhhorod, Ukraine) katya.burlaka1@gmail.com

\section{PROBLEMS AND PROSPECTS OF THE ORGANIZATION OF HISTORICAL TOURISM IN TRANSCARPATHIA}

The article analyzes the problems and prospects of the development of historical tourism in the Transcarpathian region. The author came to the conclusion that the diversity of historical and cultural monuments creates the necessary prerequisites for the intensive development of historical and, accordingly, ethnic tourism in this region.

The formation of the history of Transcarpathia took place under the influence of European countries. In particular, 11th to 15th centuries. King Stephen I joined Transcarpathia to Hungary while his son, Imre (Emeric), was titled Prince of the Ruthenians. From that time until the beginning of the 20th centuryTranscarpathia remained within the Hungarian state as its border province in the northeast. Through Transcarpathia passed a fortified defense line consisting of stockades and wooden forts manned by the local Slovak and Ruthenian population (the Ruthenian March). It was completely destroyed during the Tatar campaign against Hungary (1241), when the invaders made their way through the mountain passes. In the 13th and 14th centuries stone castles capable of withstanding a long siege were built in place of wooden stockades. Feudalism developed as well, and royal domains were transformed into gentrylatifundia, which in part survived into the 20th century. Simultaneously Transcarpathiawas subdivided according to a new komitat, or territorial-administrative structure.After the First World War Transcarpathiawas separated from Hungary, and the bulk of its territory was formed into an autonomous region within Czechoslovakia called Subcarpathian Ruthenia (PidkarpatskaRus') or Carpatho-Ukraine. A small part of Transcarpathia, located south of the Tysa River within the drainage basin of the Vyshava River (Vişeu in Romanian), became part of Romania (see Maramureş region); in Transcarpathia's western reaches, the Prešov region was allocated to Slovakia. A narrow strip of Hungarian ethnographic territory was added to Carpatho-Ukraine with the intent of securing an east-west railroad link (Košice-Chop-Khust-Rakhiv) for direct communication with the rest of Czechoslovakia and a connection, via a branch line, to Romania.

Historical memorials of Transcarpathiaare represented by wooden churches, medieval castles.

Disclosure of the theme became possible through the use of general scientific methods of cognition: analysis, synthesis, system, generalization, concreteness, historicism and dialectical method. The scientific research also uses special scientific methods of research: historical-comparative, historical-synthetic, historical-diachronic, empirical analysis, etc.

Key words: historical tourism, Transcarpathia, historical and cultural monuments, historical resources, ethnographic tourism.

Ref. 13. 
Екатерина БУРЛАКА, магистр-туризмовед, факультет туризма и международных коммуникаций ГВУЗ «Ужгородский национальный университет» (Ужгород, Украина) katya.burlaka1@gmail.com

\section{ПРОБЛЕМЫ И ПЕРСПЕКТИВЫ ОРГАНИЗАЦИИ ИСТОРИЧЕСКОГО ТУРИЗМА В ЗАКАРПАТЬЕ}

В статье проанализированы проблемы и перспективы развития исторического туризма в Закарпатской области. Автор пришла к выводу, что многообразием историко-культурньх памятников создают необходимые предпосылки для интенсивного развития исторического и соответственно этнического туризма в этом регионе.

Раскрытие темы стало возможным благодаря использованию общенаучных методов познания: анализа, синтеза, системности, обобщения, конкретности, историзма и диалектического. Использовань, также специальнонаучные методы исследования: историко-сравнительный, историко-синтетический, историко-диахронный, эмпирического анализа и тому подобное.

Ключевые слова: исторический туризм, Закарпатье, историко-культурные памятники, исторические ресурсы, этнографический туризм.

Лит. 13.

Постановка проблеми. На наш погляд, одним із пріоритетних напрямів розвитку туристичної галузі в Україні неодмінно повинен бути історичний туризм. Його основою є використання фортифікаційних та культових об'єктів. Тому питання розвитку історичного туризму і підвищення його привабливості на національному та міжнародному рівнях - особливо актуальне на сучасному етапі розвитку і становлення туристичної галузі країни. Оскільки Закарпатська область має значну кількість середньовічних замків, палаців, культових споруд та історико-культурних пам'яток, вважаємо, що цей вид туризму має стати пріоритетним.

Аналіз досліджень. Дослідження історичних аспектів туризму та історико-культурної спадщини України й відповідно Закарпаття, розглянуто у працях В. Фуртія [13], Б. Кобаля [5], В. Горбика та Г. Денисенка [3], В. Абрамова [1], М. Рутинського [9], В. Федорченка [12]та ін.

Мета статті - дослідити сучасні проблеми та тенденції розвитку історичного туризму на Закарпатті.

Виклад основного матеріалу. На наш погляд, значна кількість різноманітних пам'яток матеріальної та духовної культури України, численні мальовничі природні ландшафти та інші цінні чинники для розвитку туризму виступають об'єктивною передумовою для розробки мережі різноманітних за змістом і тривалістю туристичних маршрутів. Зокрема, розроблені тури здатні охопити всю територію України, поєднуючи екскурсійні «намиста» історико-культурної спадщини:

- Галичини;

- Волині;

- Поділля;

- Буковини;

- Карпат і Закарпаття;

- Придніпров’я, Північного Лівобережжя та Слобожанщини.

Зокрема, у багатій історико-архітектурній спадщині України визначне місце належить пам'яткам оборонної архітектури які є об’єктами історичного туризму:

- фортецям;

- замкам;

- оборонним храмам;

- міським укріпленням [8, 17-21].

Зауважимо, що упродовж багатьох століть у системі міст і містечок роль оборонних споруд була провідною. Без перебільшення можна сказати, що від рівня організації оборони залежала доля всіх поселень [9, 10-13]. 
Перші захисні укріплення у Закарпатті з'являються у бронзовому віці. Це були просто городища-гради, укріплені земляним валом. Проте найбільш завершену форму оборонної споруди мали замки XI - XVII ст.

Але якщо замки були необхідні для ведення війн, то для спокійного світського життя відомі феодальні родини намагалися будувати замки-палаци великих розмірів, з розмахом і розкішшю в інтер’єрі внутрішніх приміщень. Вони відрізнялися оригінальністю та різноманітністю архітектурних стилів зовнішнього оздоблення. Сьогодні на території Закарпаття нараховується 12 замків, збудованих у період X - XVI ст. Зводили їх у місцях, якими просувалася лінія кордону Угорської імперії, яка через Карпати здіймалася до кордонів Галицько-Волинського князівства [10, 36-39; 11, 81-5].

Можемо стверджувати, що сьогодні закарпатські замки, палаци та культові споруди мають туристичне призначення, зокрема як:

1. Музеї;

2. Картинні галереї;

3. Туристичні родзинки краю;

4. Майданчиками для театральних постановок та музичних концертів [7, 54-59].

Зокрема, закарпатські замки були збудовані у різні епохи різними правителями, різними народами. Вони були твердинями, які захищали життя, майно та інтереси свого володаря і його підданих, охороняли гористі володіння від вторгнення ворогів із заходу чи сходу, розділених Карпатським гірським хребтом [3, 143-151; 2, 28-31].

Відзначимо, що багато закарпатських замків призначалися для виконання охорони знаменитого Соляного шляху, королівської функції (Ужгородський та Замок Паланок) були і лицарські замки (Квасівський та Бронецький замки).

Загалом відзначимо, що на території Закарпаття є будівлі і руїни 12 середньовічних замків, зокрема:

1. Ужгородський (м. Ужгород) - XI ст., нині музей;

2. Мукачівський (м. Мукачево) - ХІ ст., нині музей;

3. Невицький (с. Невицьке Ужгородського району) - руїни, XIII - XVII ст;

4. Середнянський (смт. Середнє Ужгородського району) - руїни, XII - XVIII ст;

5. Чинадієвський (смт. Чинадієво Мукачівського району) - паркова споруда, XV ст.;

6. Бронецький (с. Бронька Іршавського району) - залишки, XIII - XIV ст.;

7. Квасівський (с. Квасово Берегівського району) - руїни, XII - XVI ст.;

8. Боржавський (с. Вари Берегівського району) - залишки, XI - XVII ст.;

9. Королевський (смт. Королево Виноградівського району) - руїни, XII - XVII ст.;

10. Виноградівський (м. Виноградів) - руїни, XI - XVI ст.;

11. Хустський (м. Хуст) - руїни, XIX - VIII ст.;

12. Вишківський (смт. Вишково Хустського району) - залишки, XIII - XIV ст [6, 5-8].

У контексті вищезазначеного, ми можемо запропонувати туристичний історичний маршрут «Замки Закарпаття». Він передбачає відвідування таких місцевостей області:

1. Чинадієва;

2. Мукачева;

3. Середнього;

4. Невицького;

5. Ужгорода;

6. Берегова;

7. Квасова;

8. Виноградова;

9. Королева;

10. Хуста;

11. Велятина;

12. Сільця.

Згідно із маршрутом передбачено таке: 
1 день: приїзд у смт. Чинадієво (екскурсія замком Сент-Міклош та обід) - Мукачево (панорамний огляд замку) - Середнє (екскурсія до замку) - Невицьке (огляд замку) - Ужгород (панорамний огляд замку із північно-східної сторони) - Берегово (дегустація вина) - Квасово, Берегівський р-н (поселення о 21:00 в садиби сільського туризму, вечеря).

2 день: с. Квасово (сніданок, огляд руїн замку і виїзд (08:40) - Виноградово (огляд замку Канків) - Королево (екскурсія замком Нялаб) - Хуст (обід і огляд замку) - Велятин (купання у термальному басейні) - Сільце (панорамний огляд гори замку Бодулів).

Тривалість зазначеного екскурсійного замкового маршруту 2 дні та 1 ніч [9, 59-67].

Аналіз культурної спадщини Закарпатської області дає можливість зробити висновок про забезпеченість туризму історико-культурним потенціалом, який відкриває багато нових можливостей для організації і успішної реалізації різних видів історичного туризму, зокрема таке:

1. Історико-культурного;

2. Пізнавального;

3. Відпочинкового;

4. Релігійного;

5. Етнічного;

6. Виставково-експозиційного;

7. Тематичного:

- винно-дегустаційні тури;

- кінний туризм;

- фехтування та лицарські турніри;

- бали та карнавали;

- святкування урочистих подій тощо [5, 98-102].

Однак уважаємо, що через недосконале законодавство туристичне використання історичних пам'яток у Закарпатській області, як загалом і у країні, зводиться до мінімуму. Це пов'язано 3 тим, що потребує залучення значних коштів та зусиль, а Уряд України через відсутність системних положень щодо напрямів розвитку туризму на перспективу істотним чином стримує налагодження ефективної роботи у туристичній галузі [3, 143-151].

У цьому контексті переконані, що варто було б запозичити досвід багатьох європейських та світових держав, які здатні максимально організувати використання історичних пам'яток у туристичній галузі і отримувати з цього значні дивіденди, насамперед у фінансовому плані.

На наш погляд, можна запропонувати низку інноваційних проектів, які сприяли використанню історико-культурної спадщини у туризмі. Зокрема:

1. На території всіх без винятку замків можна організовувати різноманітного роду фестивалі чи етнокультурні дійства, пов'язані з історією тої чи тої фортеці. Так, у Невицькому чи Ужгородському замку та у с. Середнє можна було б проводити середньовічні лицарські турніри, притаманні періоду доби Угорського королівства та ін.

2. Стан збереженості замків в Ужгородському районі дає змогу організовувати у них музейні експозиції різної тематики, зробити з них повноцінні скансени на зразок європейських та з часом повністю повернути вкладені в них кошти. Важливим при цьому є створення необхідних загальнодоступних інформаційних сайтів та порталів з повною довідкою про них, надання інформації про туристичну інфраструктуру місцевості [5, 98-102; 4, 67-71].

Висновок. На наш погляд, сьогодні Закарпаття є одним із найпривабливішим регіонів України для туристів. Це зумовлюється такими чинниками:

1. Курортним та рекреаційним потенціалом;

2. Мальовничими пейзажами;

3. Визначними пам'ятками історії, культури та архітектури;

4. Особливістю географічного розміщення на перетині Румунії, Словаччини, Польщі, Угорщини.

Зауважимо, що поєднання різних культур та особливостей сприяє поширенню історичного туризму у цьому регіоні та з кожним роком приваблює все більше туристів. 


\section{СПИСОК ВИКОРИСТАНИХ ДЖЕРЕЛ І ЛІТЕРАТУРИ}

1. Абрамов В. В. Історія туризму / В. В. Абрамов, М. В. Тонкошкур. - Харків: Харківська національна академія міського господарства, 2010. - 294 с.

2. Асєєв Ю. С. Історія української архітектури / Ю. С. Асєєв. - К.: Техніка, 2003. - 472 с.

3. Горбик В. О. Проблеми дослідження і збереження пам'яток історії та культури в Україні / О. Горбик, Г. Денисенко // Український історичний журнал. - 2003. - № 3. - С. 143-151.

4. Кифяк В. О. Організація туристичної діяльності в Україні / В. Кифяк. - Чернівці: Зелена Буковина, 2003. $-312 \mathrm{c}$.

5. Кобаль Б. Історія розвитку етнографічного туризму в Україні / Б. Кобаль // Східноєвропейський історичний вісник / [головний редактор В. Ільницький]. - Дрогобич: Посвіт, 2017. - Вип. 2. - С. 98-102.

6. Корсак Р. Туристичні об’єкти Закарпатської області: Збірник / Р. Корсак, М. Корсак, В. Гребенюк. Ужгород: Поліграфцентр «Ліра», 2017. - 416 с.

7. Крачило Н. П. Краєзнавство і туризм: Навчальний посібник / Н. П. Крачило. - К.: Вища школа, 1994. - $191 \mathrm{c}$.

8. Нариси історії архітектури Української РСР. - К.: Держ. вид-во літ-ри з буд-ва і архітектури УРСР, 1957. $-557 \mathrm{c}$.

9. Рутинський М. Й. Замковий туризм в Україні. Географія пам’яток фортифікаційного зодчества та перспективи їх туристичного відродження / М. Й. Рутинський // Навчальний посібник. - К.: Центр учбової літератури, 2007. - 432 с.

10. Сова П. П. Архітектурні пам’ятки Закарпаття / П. П. Сова. - Ужгород,1958. - 134 с.

11. Федака П. Пам’ятки Замкової гори / П. Федака. - Ужгород, 1999. - 197 с.

12. Федорченко В. К. Історія туризму в Україні: Навчальний посібник / В. К. Федорченко, Т. А. Дьорова. - К.: Вища школа, 2002. - 195 с.

13. Фуртій В. Розвиток туризму на Закарпатті у період Чехословаччини 1918 - 1938 pp. / В. Фуртій // Східноєвропейський історичний вісник / [головний редактор В. Ільницький]. - Дрогобич: Посвіт, 2017. Вип. 3. - С. 114-117.

\section{REFERENCES}

1. Abramov V. V. Istoriia turyzmu / V. V. Abramov, M. V. Tonkoshkur. - Kharkiv: Kharkivska natsionalna akademiia miskohoho spodarstva, 2010. - $294 \mathrm{~s}$.

2. Asieiev Yu. S. Istoriia ukrainskoi arkhitektury / Yu. S. Asieiev. - K.: Tekhnika, 2003. $-472 \mathrm{~s}$.

3. Horbyk V. O. Problemy doslidzhennia i zberezhennia pamiatok istorii ta kultury v Ukraini / O. Horbyk, H. Denysenko // Ukrainskyi istorychnyi zhurnal. - 2003. - №3. - S. 143-151.

4. Kyfiak V. O. Orhanizatsiia turystychnoi diialnosti v Ukraini / V. Kyfiak. - Chernivtsi: Zelena Bukovyna, 2003. $-312 \mathrm{~s}$.

5. Kobal B. Istoriia rozvytku etnohrafichnoho turyzmu v Ukraini / B. Kobal // Skhidnoievropeiskyi istorychnyi visnyk / [holovnyi redaktor V. Ilnytskyi]. - Drohobych: Posvit, 2017. - Vyp. 2. - S. 98-102.

6. Korsak R. Turystychni obiekty Zakarpatskoi oblasti: Zbirnyk / R. Korsak, M. Korsak, V. Hrebeniuk. Uzhhorod: Polihraftsentr «Lira», 2017. - 416 s.

7. Krachylo N. P. Kraieznavstvo i turyzm: Navchalnyi posibnyk / N. P. Krachylo. - K.: Vyshcha shkola, 1994. - $191 \mathrm{~s}$.

8. Narysy istorii arkhitektury Ukrainskoi RSR. - K.: Derzh. vyd vo lit ry z bud va i arkhitektury URSR, 1957. $-557 \mathrm{~s}$.

9. Rutynskyi M. Y. Zamkovyi turyzm v Ukraini. Heohrafiia pamiatok fortyfikatsiinoho zodchestva ta perspektyvy yikh turystychnoho vidrodzhennia / M. Y. Rutynskyi // Navchalnyi posibnyk. - K.: Tsentr uchbovoi literatury, 2007. $-432 \mathrm{~s}$.

10. Sova P. P. Arkhitekturni pamiatky Zakarpattia / P. P. Sova. - Uzhhorod,1958. - $134 \mathrm{~s}$.

11. Fedaka P. Pamiatky Zamkovoi hory / P. Fedaka. - Uzhhorod, 1999. - 197 s.

12. Fedorchenko V. K. Istoriia turyzmu v Ukraini: Navchalnyiposibnyk / V. K. Fedorchenko, T. A. Dorova. K.: Vyshcha shkola, 2002. - $195 \mathrm{~s}$.

13. Furtii V. Rozvytok turyzmu na Zakarpatti u periodChekhoslovachchyny 1918 - 1938 rr. / V. Furtii // Skhidnoievropeiskyi istorychnyi visnyk / [holovnyi redaktor V. Ilnytskyi]. - Drohobych: Posvit, 2017. - Vyp. 3. S. 114-117.

Стаття надійшла до редакиії 11.09.2017 p. 